\title{
Komparasi Metode Profile Matching Dengan Fuzzy Profile Matching Pada Pemilihan Wakil Kepala Sekolah
}

\author{
$\underline{\text { Arry Verdian }^{1}, \text { Agus Wantoro }^{2}}$ \\ Teknik Informatika, Institut Informatika dan Bisnis Darmajaya, Bandar Lampung ${ }^{1}$ \\ Sistem Informasi, Univesitas Teknokrat Indonesia, Bandar Lampung ${ }^{2}$ \\ Jl. ZA. Pagar Alam No.93, Gedong Meneng, Kec. Rajabasa, Kota Bandar Lampung ${ }^{1}$ \\ Jl. ZA. Pagar Alam No.9-11, Labuhan Ratu, Kec.Kedaton, Kota Bandar Lampung ${ }^{2}$ \\ e-mail :Verdian.2637@gmail.com ${ }^{1}$,aguswantoro@teknokrat.ac.id ${ }^{2}$
}

\begin{abstract}
Vice Principal who has high capability and professionalism is very much determined by various factors, including academic, personality, experience, creativity, innovative factors and the tendency to always achieve maximum achievement with the support of various elements of the learning environment itself. Evaluation of prospective vice principals is conducted by teachers and staff by voting. Using this method is considered inappropriate because teachers and staff only make the selection without doing a calculation. In the next period the school replaced the voting method with a calculation system by conducting tests and assessments by the committee to the vice-principal. Subsequent test results will be calculated using the weighting multiplication method of each criterion. The results of the calculation of this weight multiplication method will be compared with calculations using the Profile Mataching and Fuzzy Profile Matching methods. The results of calculations using the Profile Matching method will be compared (comparation) with the Fuzzy Profile Matching method with the data center from the results of standard calculations with the multiplication of weights and criterion values. This comparison is carried out to find out whether the application of Fuzzy Logic to the Profile Matching Method is able to provide a better proximity value than the standard Profile Matching method. The ranking results show the same results between weighted calculations with Fuzzy-Profile Matching, so that the application of Fuzzy Logic to the Profile Matching method is able to provide a better level of accuracy, so that it can be applied by the school in determining the vice-principal.
\end{abstract}

Keywords : DSS, Comparation, Fuzzy, Profile Matching, Deputy head

\begin{abstract}
Abstrak
Wakil Kepala Sekolah yang memiliki kapabilitas dan profesional yang tinggi sangat ditentukan oleh berbagai faktor, diantaranya faktor akademis, kepribadian, pengalaman, kreatifitas, inovatif dan kecenderungan untuk selalu mencapai prestasi secara maksimal dengan dukungan dari berbagai unsur di lingkungan belajar itu sendiri. Penilaian kepada calon wakil kepala sekolah dilakukan oleh guru dan staff dengan cara voting. Menggunakan cara seperti ini dirasa kurang tepat karna guru dan staff hanya melakukan pemilihan tanpa melakukan pehitungan. Pada periode berikutnya pihak sekolah mengganti cara voting dengan melakukan pengujian dan penilaian oleh panitia kepada calon wakil kepala sekolah. Hasil pengujian selanjutnya akan dihitung menggunakan metode perkalian bobot kepentingan dari setiap kriteria. Hasil perhitungan dari metode perkalian bobot inilah yang akan dibandingkan dengan perhitungan menggunakan metode Profile Matching dan Fuzzy Profile Matching. Hasil perhitungan menggunakan metode Profile Matching akan dibandingkan (comparation) dengan metode Fuzzy Profile Matching dengan data center dari hasil perhitungan standar dengan perkalian bobot dan nilai kriteria. Perbandingan ini dilakukan untuk mengetahui apakah penerapan Logika Fuzzy pada metode Profile Matching mampu memberikan nilai kedekatan yang lebih baik dari metode Profile Matching standar. Hasil perangkingan menunjukan hasil yang sama antara perhitungan terbobot dengan Fuzzy-Profile Matching, sehingga penerapan Logika Fuzzy pada metode Profile Matching mampu memberikan tingkat akurasi yang lebih baik, sehingga dapat diterapkan oleh pihak sekolah dalam menentukan wakil kepala sekolah.
\end{abstract}

Kata Kunci : SPK, Komparasi, Fuzzy, Profile Matching, Wakil Kepala Sekolah

(C) 2019 Jurnal Ilmiah MEDIA SISFO

https://doi.org/10.33998/mediasisfo.2019.13.2.652 


\section{Pendahuluan}

Pemilihan Kepala Sekolah dimaksudkan untuk menentukan seorang pegawai yang memiliki dedikasi, loyalitas dan profesionalisme yang diharapkan akan berpengaruh positif pada kinerja dan prestasi suatu instansi [1]. Pengangkatan Wakil Kepala Sekolah dengan melibatkan semua unsur yang berada di lingkungan kerja, diharapkan dapat dijadikan sarana pendukung yang kappabilitas dan profesionalitas dalam menjalankan tugasnya. Pengangkatan wakil kepala sekolah dengan cara pemilihan secara demokratis, transparan dan terbuka diharapkan dapat menjembatani antara kepentingan lembaga dan tuntutan profesionalitas, dengan demikian kedepan diharapkan lebih kondusif sebagai lembaga pendidikan yang mampu menghadapi tantangan dunia global yang serba kompetitif.

Wakil Kepala Sekolah yang memiliki kapabilitas dan profesionalitas yang tinggi sangat ditentukan oleh berbagai faktor, diantaranya faktor akademis, kepribadian, pengalaman, kreatifitas, inovatif dan kecenderungan untuk selalu mencapai prestasi secara maksimal dengan dukungan dari berebagai unsur yang berada dilingkungan belajar itu sendiri. Penilaian kepada calon wakil kepala sekolah dilakukan oleh guru dan staff sekolah dengan cara voting. Cara seperti ini dirasa kurang tepat karena guru dan staff hanya melakukan pemilihan tanpa dilakukan pehitungan dari masing-masing calon wakil kepala sekolah.

Pada periode berikutnya pihak sekolah mengganti cara voting dengan perhitungan melalui pengujian dan penilaian oleh panitia kepada calon wakil kepala sekolah. Hasil pengujian selanjutnya akan dihitung menggunakan metode perkalian bobot kepentingan dari setiap kriteria. Hasil perhitungan dari metode perkalian bobot inilah yang akan dibandingkan dengan perhitungan menggunakan metode Profile Matching dan Fuzzy Profile Matching. Metode Profile Matching digunakan dalam pengambilan keputusan dengan mengasumsikan bahwa terdapat tingkat variabel prediktor yang ideal yang harus dipenuhi oleh subyek yang diteliti, bukannya tingkat minimal yang harus dipenuhi atau dilewati. Metode ini menggunakan konversi nilai pada tahap awal sebelum dilakukan perhitungan [2].

Penggunaan metode profile matching dapat dapat meningkatkan akurasi penilaian proposal secara profesional dan proporsional berdasarkan kriteria penilaian yang telah ditentukan [3]. Namun, disisi lain Metode Profile Matching juga memiliki kelemahan pada proses konversi nilai interval (range) yang dapat membuat hasil perhitungan kurang akurat. Perlu dilakukan pengembangan pada metode ini yang dikombinasi dengan logika fuzzy menggunakan fungsi keanggotaan pada tahapan konversi nilai interval. Logika fuzzy mampu memberikan nilai dari suatu ketidakpastian dan merupakan cara yang tepat untuk memetakan suatu ruang input ke dalam suatu ruang output [4].

Penerapan fuzzy pada metode Profile Matching mampu menjadikan tahapan lebih sederhana. Hasil perhitungan menggunakan metode Profile Matching akan dibandingkan (comparation) dengan metode Fuzzy Profile Matching dengan data center dari hasil perhitungan standar dengan perkalian bobot dan nilai kriteria. Perbandingan ini dilakukan untuk mengetahui apakah penerapan Logika Fuzzy pada Metode Profile Matching mampu memberikan nilai kedekatan yang lebih baik dari metode Profile Matching standar.

\section{Tinjauan Pustaka}

\subsection{Sistem Pendukung Keputusan}

Sistem pendukung keputusan merupakan sistem informasi berbasis komputer yang interaktif, fleksibel, dan mudah disesuaikan, terutama dikembangkan untuk mendukung penyelesaian solusi dari masalah manajemen untuk pengambilan keputusan yang lebih baik [5]. Sistem ini digunakan untuk membantu pengambilan keputusan dalam situasi yang semi terstruktur dan situasi yang tidak terstruktur, di mana tidak seorang pun tahu secara pasti bagaimana keputusan seharusnnya dibuat [1].

\subsection{Profile Matching}

Metode profile matching atau pencocokan profil adalah metode yang sering sebagai mekanisme dalam pengambilan keputusan dengan mengasumsikan bahwa terdapat tingkat variabel prediktor yang ideal yang harus dipenuhi oleh subyek yang diteliti, bukannya tingkat minimal yang harus dipenuhi atau dilewati [2]. Dalam proses profile matching secara garis besar merupakan proses membandingkan antara nilai data aktual dari suatu profile yang akan dinilai dengan nilai profil yang diharapkan, sehingga dapat diketahui perbedaan kompetensinya (GAP), semakin kecil gap yang dihasilkan maka bobot nilainya 
semakin besar yang berarti memiliki peluang lebih besar untuk direkomendasikan untuk terpilih. Pemilihan wakil sekolah dilakukan dengan meghitung kecocokan nilai alternatif dengan nilai yang telah ditetapkan dalam standar pemilihan wakil kepala sekolah oleh pihak instansi. Cara ini dapat diselesaikan menggunakan metode pencocokan profile atau metode Profile Matching. Metode ini memiliki tingkat obyektifitas yang lebih baik karena untuk mengukur nilai setiap indikator variabel. Adapun tahapantahapan dari metode Profile Matching sebagai berikut [2] :

a. Menentukan Kriteria

Kriteria yang digunakan dalam yaitu pendukung keputusan pemilihan calon karyawan yaitu penilaian berkas lamaran kerja dengan kriteria Portofolio, Penilaian Kinerja, Penulisan Karya Ilmiah, Wawancara dan Tes Tertulis

b. Konversi Nilai Interval

Tahap ini menggunakan logika fuzzy dengan menggunakan kurva linier dan fungsi keanggotaan

c. Pemberian Nilai Target / Profile Ideal

Pemberian nilai ideal berdasarkan nilai maksimal dari data-data alternative atau nilai rata-rata sesuai dengan kebijakan pengambil keputusan

d. Hitung GAP dan Pembobotan GAP Menggunakan Logika Fuzzy

e. Pembobotan GAP yang digunakan $0-5$

Tabel 1. Pembobotan GAP [2]

\begin{tabular}{ccl}
\hline GAP & Bobot & \multicolumn{1}{c}{ Keterangan } \\
\hline 0 & 5 & Tidak ada selisih (kompetensi sesuai kebutuhan) \\
1 & 4.5 & Kompetensi individu kelebihan 1 tingkat \\
-1 & 4 & Kompetensi individu kekurangan 1 tingkat \\
2 & 3.5 & Kompetensi individu kelebihan 2 tingkat \\
-2 & 3 & Kompetensi individu kekurangan 2 tingkat \\
3 & 2.5 & Kompetensi individu kelebihan 3 tingkat \\
-3 & 2 & Kompetensi individu kekurangan 3 tingkat \\
4 & 1.5 & Kompetensi individu kelebihan 4 tingkat \\
-4 & 1 & Kompetensi individu kekurangan 4 tingkat \\
\hline
\end{tabular}

f. Perhitungan dan pengelompokan Core Factor dan Secondary Factor

Rumus menghitung Nilai Core Factor (NCF):

$N C F=\frac{\sum N C(i, s, p)}{\sum I C}$

dengan NCF adalah nilai rata-rata core factor, $\mathrm{NC}(\mathrm{i}, \mathrm{s}, \mathrm{p})$ adalah jumlah total nilai core factor dan IC adalah jumlah item core factor.

Rumus menghitung Nilai Secondary Factor (NSF) :

$N S F=\frac{\sum N C(i, s, p)}{\sum I C}$

dengan NSF adalah nilai rata-rata secondary factor, NS (i,s,p) adalah jumlah nilai total secondary factor dan IS adalah jumlah item secondary factor.

g. Perhitungan Nilai Total

Dari perhitungan setiap aspek yang diatas, berikutnya dihitung nilai total berdasarkan presentase dari Core Factor dan Secondary Factor :

$\mathrm{N}(\mathrm{i}, \mathrm{s}, \mathrm{p})=(55) \% \cdot \mathrm{NCF}(\mathrm{i}, \mathrm{s}, \mathrm{p})+(45) \% \cdot \mathrm{NSF}(\mathrm{i}, \mathrm{s}, \mathrm{p})$

dengan $\mathrm{NCF}(\mathrm{i}, \mathrm{s}, \mathrm{p})$ adalah nilai rata-rata core factor, $\mathrm{NSF}(\mathrm{i}, \mathrm{s}, \mathrm{p})$ adalah nilai rata-rata secondary factor, $\mathrm{N}(\mathrm{i}, \mathrm{s}, \mathrm{p})$ adalah nilai total dari aspek serta $(\mathrm{x}) \%$ merupakan nilai persen yang diinputkan.

h. Perangkingan

Hasil akhir dari proses profile matching adalah ranking dari kandidat yang diajukan untuk memilih hasil yang terbaik [2]. Penentuan ranking mengacu pada hasil perhitungan tertentu.

Ranking $=(\mathrm{x}) \% \cdot \mathrm{Np}+(\mathrm{x}) \% \cdot \mathrm{Nk}+(\mathrm{x}) \% \cdot \mathrm{Nb}+(\mathrm{x}) \% \cdot \mathrm{Nw}+(\mathrm{x}) \% \cdot \mathrm{Nt}$ 
dengan $\mathrm{Np}$ merupakan nilai portofolio, $\mathrm{Nk}$ adalah nilai kinerja, $\mathrm{Nb}$ adalah nilai presentasi (Best Practice), $\mathrm{Nw}$ adalah nilai wawancara, $\mathrm{Nt}$ adalah Nilai Tertulis serta $(\mathrm{x}) \%$ adalah nilai persentase.

\subsection{Logika Fuzzy}

Teori himpunan fuzzy dapat digunakan untuk merepresentasikan masalah ketidakpastian. Sebuah bilangan fuzzy biasa memiliki himpunan fuzzy yang ditandai dengan pemberian interval dari 0-1[5]. Logika fuzzy menggunakan fungsi keanggotaan dengan menggunakan kurva yang menunjukkan pemetaan titik-titik input data ke dalam nilai keanggotaannya yang memiliki interval antara 0 sampai 1 . Salah satu cara yang dapat digunakan untuk mendapatkan nilai keanggotaan adalah dengan melalui pendekatan fungsi [6]. Ada beberapa fungsi yang bisa digunakan Kurva Segitiga pada dasarnya merupakan gabungan antara 2 garis (linear) [4]. seperti terlihat pada Gambar 1.

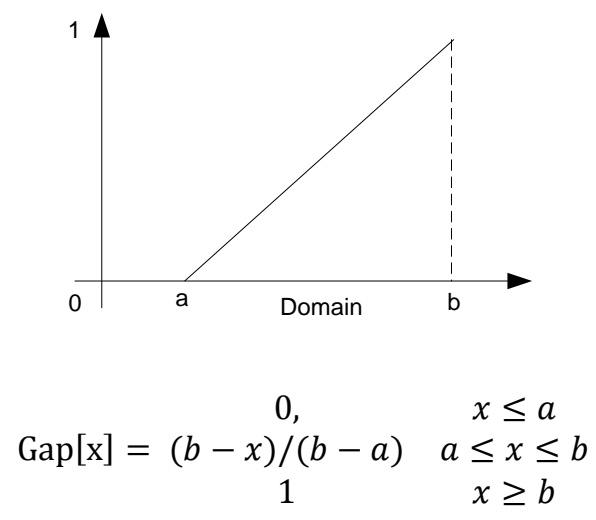

Gambar 1. Kurva Linier Naik [4]

\subsection{Fuzzy Profile Matching}

Fuzzy Profile Matching merupakan kombinasi Logika Fuzzy dengan metode Profile Matching. Tahapan yang digunakan adalah tahapan pada metode Profile Macthing yang dikombinasi dengan Logika Fuzzy menggunakan fungsi keanggotaan yang digunakan untuk perhitungan konversi nilai interval, perhitungan GAP dan pembobotan GAP.

\subsection{Penelitian Sejenis}

Evaluasi empiris menunjukkan metode ini bekerja dengan baik (Akurasi 97\%) terhadap serangan dan keinginan phishing. Metode ini juga paling akurat terhadap situs yang paling mirip dengan situs nyata (yang paling sulit untuk pengguna dideteksi)[7]. Penelitian lebih lanjut tentang pendekatan ini akan membantu untuk membuat sistem yang kuat untuk deteksi phishing dengan intervensi manusia. Profile Matching memiliki tingkat obyektifitas yang lebih baik karena untuk mengukur nilai setiap indikator variabel penilaian diturunkan lagi dengan sub-indikator dan dibobotkan dengan menggunakan parameter penilaian serta dihitung dengan menggunakan mekanisme pengambilan keputusan dengan mengasumsikan bahwa terdapat tingkat variabel prediktor yang ideal yang harus dipenuhi oleh subyek [2]. Berbeda dengan proses penilaian manual yang hanya memasukkan nilai tingkat keterpenuhan dari setiap indikator dengan menuliskan angka dan dihitung hanya dengan menjumlahkannya. Penerapan system pendukung keputusan menggunakan metode Profile Matching memberikan kemudahan kepada pemerintah kabupaten Tanggamus untuk penataan posisi pegawai di masing-masing lembaga yang diperlukan [8]. Sistem Logika Fuzzy yang dikombinasikan dengan metode Profile Matching dalam pencocokan profil DNA menggunakan distribusi penanda alel fungsi kepadatan probabilitas sebagai fungsi keanggotaan, memungkinkan untuk memberitahu etnis kesamaan antara dua profil DNA dengan cepat dan sederhana [9]. Penelitian lain melakukan komparasi hasil antara model profile matching dan model profile matching menggunaan fuzzifikasi sebagai sebuah tinjauan. Pemilihan makalah terbaik penggunaan model modifikasi profile matching dan fuzzifikasi lebih tepat digunakan dibandingkan dengan model profile matching [10]. Berdasarkan beberapa penelitian, penerapan logika fuzzy pada metode Profile Matching dapat memberikan hasil yang lebih baik. Pada penelitian ini akan 
membandingkan hasil perhitungan pada metode Profile Matching dan Fuzzyfikasi Profile Matching pada pemilihan wakil kepala sekolah.

\section{Metodologi}

\subsection{Pengumpulan Data}

Data yang digunakan adalah data calon wakil kepala sekolah yang diambil dari SMK Persada Bandarlampung yang diajukan oleh kepala sekolah untuk dipilih menjadi guru terbaik. Terdapat 5 data calon wakil kepala sekolah yang diajukan untuk dilakukan penilaian menjadi wakil kepala sekolah.

Tabel 2. Data Alternatif

\begin{tabular}{llcccccc}
\hline No & \multicolumn{1}{c}{ Nama } & Pangkat/Jabatan & Portofolio & Kinerja & $\begin{array}{c}\text { Karya } \\
\text { Ilmiah }\end{array}$ & Tertulis & Wawancara \\
\hline 1 & Drs.H. Arsilazim & Pembina IV/A & 75 & 80 & 70 & 90 & 85 \\
2 & Dra. Hening Pratiwi & Pembina IV/A & 90 & 75 & 85 & 70 & 75 \\
3 & Dra. Hj. Nur'isnamuly ati & Pembina IV/A & 80 & 65 & 65 & 85 & 70 \\
4 & Drs.Sumarn & Pembina IV/A & 65 & 85 & 65 & 75 & 80 \\
5 & Dra. Hj. Zahararamli, M.Si & Pembina IV/A & 85 & 80 & 90 & 70 & 75 \\
\hline
\end{tabular}

\subsection{Parameter dan Kriteria}

Parameter dan kriteria yang digunakan yaitu mengacu pada buku panduan pemilihan kepala sekolah tahun 2018 [1]. Parameter dan Kriteria yang akan dihitung memiliki beberapa aspek, yaitu :

1. Portofolio, memiliki 4 faktor :
a. Jumlah Penghargaan
b. Jumlah Mengikuti Pelatihan
c. Prestasi
d. Penugasan

2. Penilaian Kinerja, memiliki 4 aspek :
a. Tanggung Jawab
b. Kejujuran
c. Kedisiplinan
d. Kerjasama

3. Karya Ilmiah, memiliki 4 aspek :
a. Relevansi dengan Pelajaran
b. Metode Pemecahan Masalah
c. Inovasi
d. Hasil

4. Tes Tertulis, memiliki 2 aspek yaitu :

a. Tes Kompetensi Profesional

b. Tes Wawasan Kependidikan

5. Wawancara, memiliki 4 aspek yaitu :
a. Komitmen
b. Argumentasi
c. Kepribadian
d. Penunjang

\subsection{Metode Pembobotan}

Perhitungan voting dikembangkan oleh pihak sekolah dengan perhitungan perkalian antara nilai dan bobot kriteria. Bobot kriteria menggunakan bobot presentase yang dapat dilihat pada table 3 . 
Tabel 3. Data Alternatif dan Bobot Persentase (\%)

\begin{tabular}{llcccccc}
\hline No & \multicolumn{1}{c}{ Nama } & Pangkat/Jabatan & Portofolio & Kinerja & $\begin{array}{c}\text { Karya } \\
\text { Ilmiah }\end{array}$ & Tertulis & Wawancara \\
\hline 1 & Drs.H. Arsilazim & Pembina IV/A & 75 & 80 & 70 & 90 & 85 \\
2 & Dra. Hening Pratiwi & Pembina IV/A & 90 & 75 & 85 & 70 & 75 \\
3 & Dra. Hj. Nur'isnamuly ati & Pembina IV/A & 80 & 65 & 65 & 85 & 70 \\
4 & Drs.Sumarn & Pembina IV/A & 65 & 85 & 65 & 75 & 80 \\
5 & Dra. Hj. Zahararamli, M.Si & Pembina IV/A & 85 & 80 & 90 & 70 & 75 \\
\hline \multicolumn{2}{r}{ Bobot (\%) } & & $\mathbf{1 5 \%}$ & $\mathbf{2 5 \%}$ & $\mathbf{1 5 \%}$ & $\mathbf{2 5 \%}$ & $\mathbf{2 0 \%}$ \\
\hline
\end{tabular}

\subsection{Perhitungan Metode Profile Matching}

Metode profile matching atau pencocokan profil adalah metode yang serin gsebagai mekanisme dalam pengambilan keputusan dengan mengasumsikan bahwa terdapat tingkat variabel prediktor yang ideal yang harus dipenuhi oleh subyek yang diteliti [2]

Tabel 4. Nilai Kriteria Portofolio

\begin{tabular}{clccccc}
\hline No & \multicolumn{1}{c}{ Nama } & Pangkat/Jabatan & Penghargaan & Pelatihan & Prestasi & Penugasan \\
\hline 1 & Drs.H. Arsilazim & Pembina IV/A & 75 & 85 & 75 & 65 \\
2 & Dra. Hening Pratiwi & Pembina IV/A & 85 & 88 & 92 & 95 \\
3 & Dra. Hj. Nur'isnamulyati & Pembina IV/A & 80 & 75 & 85 & 80 \\
4 & Drs.Sumarn & Pembina IV/A & 60 & 65 & 70 & 65 \\
5 & Dra. Hj. Zahararamli, M.Si & Pembina IV/A & 80 & 90 & 85 & 85 \\
\hline
\end{tabular}

Tabel 5. Perhitungan GAP Kriteria Portofolio

\begin{tabular}{clccccc}
\hline No & \multicolumn{1}{c}{ Nama } & Pangkat/Jabatan & Penghargaan & Pelatihan & Prestasi & Penugasan \\
\hline 1 & Drs.H. Arsilazim & Pembina IV/A & 2 & 4 & 2 & 1 \\
2 & Dra. Hening Pratiwi & Pembina IV/A & 4 & 5 & 5 & 5 \\
3 & Dra. Hj. Nur'isnamuly ati & Pembina IV/A & 3 & 2 & 4 & 3 \\
4 & Drs.Sumarn & Pembina IV/A & 1 & 1 & 1 & 1 \\
5 & Dra. Hj. Zahararamli, M.Si & Pembina IV/A & 3 & 5 & 4 & 4 \\
\hline \multicolumn{1}{c}{ Nilai Target } & & $\mathbf{5}$ & $\mathbf{5}$ & $\mathbf{5}$ & $\mathbf{5}$ \\
\hline 1 & Drs.H. Arsilazim & Pembina IV/A & -3 & -1 & -3 & -4 \\
2 & Dra. Hening Pratiwi & Pembina IV/A & -1 & 0 & 0 & 0 \\
3 & Dra. Hj. Nur'isnamulyati & Pembina IV/A & -2 & -3 & -1 & -2 \\
4 & Drs.Sumarn & Pembina IV/A & -4 & -4 & -4 & -4 \\
5 & Dra. Hj. Zahararamli, M.Si & Pembina IV/A & -2 & 0 & -1 & -1 \\
\hline
\end{tabular}

Tabel 6. Nilai Pembobotan GAP

\begin{tabular}{clccccc}
\hline No & \multicolumn{1}{c}{ Nama } & Pangkat/Jabatan & Penghargaan & Pelatihan & Prestasi & Penugasan \\
\hline 1 & Drs.H. Arsilazim & Pembina IV/A & 2 & 4 & 2 & 1 \\
2 & Dra. Hening Pratiwi & Pembina IV/A & 4 & 5 & 5 & 5 \\
3 & Dra. Hj. Nur'isnamuly ati & Pembina IV/A & 3 & 2 & 4 & 3 \\
4 & Drs.Sumarn & Pembina IV/A & 1 & 1 & 1 & 1 \\
5 & Dra. Hj. Zahararamli, M.Si & Pembina IV/A & 3 & 5 & 4 & 4 \\
\hline
\end{tabular}

Semua nilai kriteria dikonversi kedalam skala 5 yang selanjutnya dihitung untuk mendapat nilai GAP dan pembobotan GAP. Tahapan selanjutnya menghitung NCF dan NSF seperti pada tabel 7.

Tabel 7. Nilai NCF dan NSF Kriteria Portofolio

\begin{tabular}{llcccccccc}
\hline \multirow{2}{*}{ No } & \multicolumn{1}{c}{ Nama } & Pangkat/Jabatan & $\begin{array}{c}\text { Pengharg } \\
\text { aan }\end{array}$ & Pelatihan & Prestasi Penugasan & NCF & NSF & Total \\
\hline 1 & Drs.H. Arsilazim & Pembina IV/A & 2 & 4 & 2 & 1 & 2 & 2.5 \\
2 & Dra. Hening Pratiwi & Pembina IV/A & 4 & 5 & 5 & 5 & 4.5 & 5 & 4.725 \\
3 & Dra. Hj. Nur'isnamuly ati & Pembina IV/A & 3 & 2 & 4 & 3 & 3.5 & 2.5 & 3.05 \\
4 & Drs.Sumarn & Pembina IV/A & 1 & 1 & 1 & 1 & 1 & 1 \\
5 & Dra. Hj. Zahararamli, M.Si & Pembina IV/A & 3 & 5 & 4 & 4 & 3.5 & 4.5 & 3.95 \\
\hline
\end{tabular}


Tabel 8. Nilai NCF dan NSF Kriteria Kinerja

\begin{tabular}{clccccccc}
\hline No & \multicolumn{1}{c}{ Nama } & Pangkat/Jabatan & T. Jawab Kejujuran & Disiplin & K.Sama & NCF & NSF & Total \\
\hline 1 & Drs.H. Arsilazim & Pembina IV/A & 2 & 4 & 3 & 4 & 2.5 & 4 \\
2 & Dra. Hening Pratiwi & Pembina IV/A & 1 & 3 & 3 & 1 & 2 & 2 \\
3 & Dra. Hj. Nur'isnamuly ati & Pembina IV/A & 1 & 2 & 1 & 1 & 1 & 1.5 \\
4 & Drs.Sumarn & Pembina IV/A & 3 & 5 & 4 & 5 & 3.5 & 5 \\
5 & Dra. Hj. Zahararamli, M.Si & Pembina IV/A & 3 & 2 & 4 & 3 & 3.5 & 2.5 \\
\hline
\end{tabular}

Tabel 9. Nilai NCF dan NSF Kriteria Karya Ilmiah

\begin{tabular}{|c|c|c|c|c|c|c|c|c|c|}
\hline No & Nama & Pangkat/Jabatan & Relevansi & Metode & Inovasi & Hasil & NCF & NSF & Total \\
\hline 1 & Drs.H. Arsilazim & Pembina IV/A & 1 & 2 & 2 & 1 & 1.5 & 1.5 & 1.50 \\
\hline 2 & Dra. Hening Pratiwi & Pembina IV/A & 4 & 5 & 3 & 4 & 3.5 & 4.5 & 3.95 \\
\hline 3 & Dra. Hj. Nur'isnamuly ati & Pembina IV/A & 1 & 1 & 2 & 1 & 1.5 & 1 & 1.28 \\
\hline 4 & Drs.Sumarn & Pembina IV/A & 1 & 1 & 2 & 1 & 1.5 & 1 & 1.28 \\
\hline 5 & Dra. Hj. Zahararamli, M.Si & Pembina IV/A & 5 & 4 & 5 & 5 & 5 & 4.5 & 4.78 \\
\hline
\end{tabular}

Tabel 10. Nilai NCF dan NSF Kriteria Tes Tertulis

\begin{tabular}{clcccccc}
\hline No & \multicolumn{1}{c}{ Nama } & Pangkat/Jabatan & TKP & TWK & NCF & NSF & Total \\
\hline 1 & Drs.H. Arsilazim & Pembina IV/A & 4 & 5 & 4 & 5 & 4.45 \\
2 & Dra. Hening Pratiwi & Pembina IV/A & 1 & 2 & 1 & 2 & 1.45 \\
3 & Dra. Hj. Nur'isnamuly ati & Pembina IV/A & 5 & 4 & 5 & 4 & 4.55 \\
4 & Drs.Sumarn & Pembina IV/A & 2 & 3 & 2 & 3 & 2.45 \\
5 & Dra. Hj. Zahararamli, M.Si & Pembina IV/A & 1 & 2 & 1 & 2 & 1.45 \\
\hline
\end{tabular}

Tabel 11. Nilai NCF dan NSF Kriteria Wawancara

\begin{tabular}{cllcccccc}
\hline No & \multicolumn{1}{c}{ Nama } & Pangkat/Jabatan & Komitmen Argumen & Pribadi & Penunjang & NCF & NSF & Total \\
\hline 1 & Drs.H. Arsilazim & Pembina IV/A & 5 & 3 & 4 & 4 & 4.5 & 3.5 \\
2 & Dra. Hening Pratiwi & Pembina IV/A & 2 & 3 & 4 & 1 & 3 & 2 \\
3 & Dra. Hj. Nur'isnamuly ati & Pembina IV/A & 3 & 1 & 2 & 1 & 2.05 & 1 \\
4 & Drs.Sumarn & Pembina IV/A & 2 & 3 & 4 & 3 & 3 & 3 \\
5 & Dra. Hj. Zahararamli, M.Si Pembina IV/A & 1 & 2 & 3 & 4 & 2.53 & 3 \\
\hline
\end{tabular}

\subsection{Perhitungan Fuzzy-Profile Matching}

Merupakan kombinasi Logika Fuzzy dengan metode Profile Matching. Tahapan yang digunakan adalah tahapan pada metode Profile Macthing yang dikombinasi dengan Logika Fuzzy menggunakan fungsi keanggotaan yang digunakan untuk perhitungan konversi nilai interval, perhitungan GAP dan pembobotan GAP yang dapat dilihat pada Gambar 2.

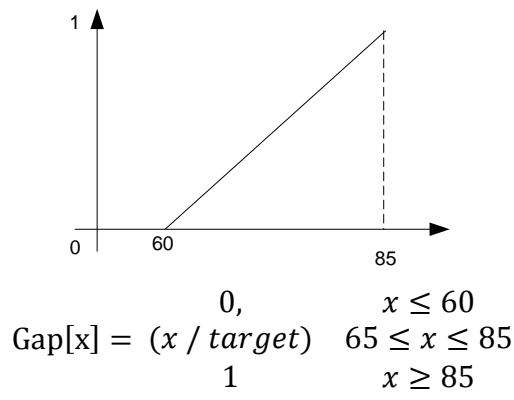

Gambar 2. Kurva Linier Kriteria Portofolio

Tabel 12. Perhitungan GAP Parameter Portofolio Kriteria Penghargaan

\begin{tabular}{clcc}
\hline No & \multicolumn{1}{c}{ Nama } & Pangkat/Jabatan & Bobot GAP \\
\hline 1 & Drs.H. Arsilazim & Pembina IV/A & 0.600 \\
2 & Dra. Hening Pratiwi & Pembina IV/A & 1 \\
3 & Dra. Hj. Nur'isnamuly ati & Pembina IV/A & 0.941 \\
4 & Drs.Sumarn & Pembina IV/A & 0.706 \\
5 & Dra. Hj. Zahararamli, M.Si & Pembina IV/A & 0.941 \\
\hline
\end{tabular}


Semua parameter dan kriteria dihitung menggunakan kurva linier naik dengan fungsi keanggotaan. Hasil dari perhitungan menggunakan kombinasi fuzzy dan profile matching menghasil nilai akhir pada tabal 14.

\section{Hasil dan Pembahasan}

Berdasarkan perhitungan perkalian antara nilai kriteria dengan bobot, maka nilai tertinggi ditampilkan pada tabel 13.

Tabel 13. Hasil Perhitungan Metode Perkalian Bobot

\begin{tabular}{clccc}
\hline No & \multicolumn{1}{c}{ Nama } & Pangkat/Jabatan & Nilai & Rank \\
\hline 1 & Drs.H. Arsilazim & Pembina IV/A & 81.250 & 1 \\
2 & Dra. Hening Pratiwi & Pembina IV/A & 77.500 & 3 \\
3 & Dra. Hj. Nur'isnamulyati & Pembina IV/A & 73.250 & 5 \\
4 & Drs.Sumarn & Pembina IV/A & 75.500 & 4 \\
5 & Dra. Hj. Zahararamli, M.Si & Pembina IV/A & 78.750 & 2 \\
\hline
\end{tabular}

Hasil perhitungan menggunakan metode Profile Matching didapatkan nilai perangkingan dapat dilihat pada tabel 14.

Tabel 14. Nilai Akhir (Ranking) Metode Profile Matching

\begin{tabular}{cllccccccc}
\hline No & \multicolumn{1}{c}{ Nama } & Pangkat & Portofolio & Kinerja & K.Ilmiah & Tertulis & Wawancarc & Total & Rank \\
\hline 1 & Drs.H. Arsilazim & Pembina IV/A & 2.225 & 3.175 & 1.500 & 4.450 & 4.050 & 3.275 & 1 \\
2 & Dra. Hening Pratiwi & Pembina IV/A & 4.725 & 2.000 & 3.950 & 1.450 & 2.550 & 2.674 & 3 \\
3 & Dra. Hj. Nur'isnamuly ati & Pembina IV/A & 3.050 & 1.225 & 1.275 & 4.550 & 1.825 & 2.458 & 5 \\
4 & Drs.Sumarn & Pembina IV/A & 1.000 & 4.175 & 1.275 & 2.450 & 3.000 & 2.598 & 4 \\
5 & Dra. Hj. Zahararamli & Pembina IV/A & 3.950 & 3.050 & 4.775 & 1.450 & 2.450 & 2.924 & 2 \\
\hline \multicolumn{2}{r}{ Bobot } & & $\mathbf{1 5 \%}$ & $\mathbf{2 5 \%}$ & $\mathbf{1 5 \%}$ & $\mathbf{2 5 \%}$ & $\mathbf{2 0 \%}$ \\
\hline
\end{tabular}

Hasil perhitungan menggunakan metode Fuzzy-Profile Matching didapatkan nilai perangkingan dapat dilihat pada tabel 15 .

Tabel 15. Hasil Perangkingan Kombinasi Fuzzy - Profile Matching

\begin{tabular}{clcccccccc}
\hline No & \multicolumn{1}{c}{ Nama } & Pangkat & Portofolio & Kinerja & K.Ilmiah & Tertulis & Wawancara & Total & Rank \\
\hline 1 & Drs.H. Arsilazim & Pembina IV/A & 0.756 & 0.939 & 0.765 & 0.981 & 0.991 & 0.906 & 1 \\
2 & Dra. Hening Pratiwi & Pembina IV/A & 0.995 & 0.886 & 0.900 & 0.762 & 0.864 & 0.869 & 3 \\
3 & Dra. Hj. Nur'isnamuly ati & Pembina IV/A & 0.890 & 0.765 & 0.720 & 0.938 & 0.863 & 0.840 & 5 \\
4 & Drs.Sumarn & Pembina IV/A & 0.720 & 1 & 0.715 & 0.819 & 0.942 & 0.858 & 4 \\
5 & Dra. Hj. Zahararamli, M.Si & Pembina IV/A & 0.939 & 0.948 & 0.983 & 0.765 & 0.895 & 0.896 & 2 \\
\hline
\end{tabular}

Berdasarkan hasil perhitungan menggunakan tiga (3) metode yaitu metode perkalian bobot yang dibandingkan dengan metode Profile Matching dan Fuzzy Profile Matcing, maka didapatkan nilai perbandingan pada tabel 16 .

Tabel 16. Hasil Komparasi Ketiga Metode

\begin{tabular}{|c|c|c|c|c|c|c|c|c|}
\hline \multirow{2}{*}{ No } & \multirow{2}{*}{ Nama } & \multirow{2}{*}{ Pangkat/Jabatan } & \multicolumn{2}{|c|}{ Standar } & \multicolumn{2}{|c|}{$\mathbf{P M}$} & \multicolumn{2}{|c|}{ FPM } \\
\hline & & & Total & Rank & Total & Rank & Total & Rank \\
\hline 1 & Drs.H. Arsilazim & Pembina IV/A & 81.25 & 1 & 3.28 & 1 & 0.906 & 1 \\
\hline 2 & Dra. Hening Pratiwi & Pembina IV/A & 77.5 & 3 & 2.67 & 4 & 0.869 & 3 \\
\hline 3 & Dra. Hj. Nur'isnamuly ati & Pembina IV/A & 73.25 & 5 & 2.46 & 5 & 0.840 & 5 \\
\hline 4 & Drs.Sumarn & Pembina IV/A & 75.5 & 4 & 2.60 & 3 & 0.858 & 4 \\
\hline 5 & Dra. Hj. Zahararamli, M.Si & Pembina IV/A & 78.75 & 2 & 2.92 & 2 & 0.896 & 2 \\
\hline
\end{tabular}

Hasil perhitungan menggunakan 3 metode menunjukkan perangkingan pada metode perkalian bobot sama dengan hasil perhitungan pada metode Fuzzy-Profile Matching. 


\section{Kesimpulan}

Berdasarkan hasil pembahasan perbandingan menggunakan ketiga metode, dengan membandingkan data center hasil perhitungan dari perhitungan perkalian pembobotan standar dan metode Profile Matching dengan Fuzzy-Profile Matching, maka dapat disimpulkan bahwa penerapan Logika Fuzzy menggunakan kurva linier naik dengan fungsi keanggotaan yang diterapkan pada metode Profile Matching untuk menghitung nilai GAP mampu memberikan nilai perangkingan yang sama dengan perhitungan metode perkalian pembobotan standar dibandingkan dengan perhitungan menggunakan metode Profile Matching.

\section{Daftar Rujukan}

[1] T. G. S. Persada, Pedoman Pemilihan Wakil Kepala Sekolah SMK Persada Bandar Lampung Tahun 2018, Kedua., no. 8. Bandar Lampung: SMK Persadar Bandar Lampung, 2018.

[2] A. Suhartanto, Kusrini, and Henderi "Decision Support System Untuk Penilaian Kinerja Guru Dengan Metode Profile Matching," J. Komput. Terap., vol. 2, no. 2, pp. 149-158, 2016.

[3] E. Faizal, "Implementasi Metode Profile matching untuk Penentuan Penerimaan Usulan Penelitian Internal Dosen STMIK El Rahma,” J. Speed - Sentra Penelit. Eng. dan Edukasi, vol. 6, no. 1, pp. 60-65, 2014.

[4] L. A. Zadeh and S. Jose, "The Concept of a Linguistic Variable II," Electr. Eng., vol. 357, pp. 301357, 1975.

[5] S. Kusumadewi, and H. Purnomo, Aplikasi Logika Fuzzy untuk Pendukung Keputusan, vol. kedua. Yogyakarta: Graha Ilmu, 2010.

[6] G. M. Foody and D. P. Cox, "International Journal of Remote Sensing Sub-pixel land cover composition estimation using a linear mixture model and fuzzy membership functions," Int. J. Remote Sens., vol. 15, no. 3, pp. 619-631, 1994.

[7] S. Afroz, "Phishzoo: An automated web phishing detection approach based on profiling and fuzzy matching," 2009.

[8] T. Susilowati, E. Y. Anggraeni, Fauzi, W. Andewi, Y. Handayani, and A. Maseleno, "Using Profile Matching Method to Employee Position Movement," Int. J. Pure Appl. Math., vol. 118, no. 7 Special Issue, 2018.

[9] R. N. Hartono, M. R. Widyanto, and N. Soedarsono, "Fuzzy logic system for DNA profile matching with embedded ethnic inference," Proc. - 2010 2nd Int. Conf. Adv. Comput. Control Telecommun. Technol. ACT 2010, pp. 69-73, 2010.

[10] D. Kurniawati, "Komparasi Hasil Antara Model Profile Matching Dan Model Profile Matching Menggunaan Fuzzifikasi sebagai Sebuah Tinjauan,” J. Teknol. Inf., vol. 10, p. 13, 2015. 